\title{
An Intermediate Report on the James Bayou Survey, Marion County, Texas: A Search for Caddo Village
}

Claude McCrocklin

Unknown

Follow this and additional works at: https://scholarworks.sfasu.edu/ita

Part of the American Material Culture Commons, Archaeological Anthropology Commons, Environmental Studies Commons, Other American Studies Commons, Other Arts and Humanities Commons, Other History of Art, Architecture, and Archaeology Commons, and the United States History Commons

Tell us how this article helped you.

This Article is brought to you for free and open access by the Center for Regional Heritage Research at SFA ScholarWorks. It has been accepted for inclusion in Index of Texas Archaeology: Open Access Gray Literature from the Lone Star State by an authorized editor of SFA ScholarWorks. For more information, please contact cdsscholarworks@sfasu.edu. 


\section{An Intermediate Report on the James Bayou Survey, Marion County, Texas: A Search for Caddo Village}

\section{Creative Commons License}

\section{(c) (1) \&}

This work is licensed under a Creative Commons Attribution-NonCommercial 4.0 International License 
An Intermediate Report on the

James Bayou Survey, Marion County, Texas:

A Search for Caddo Village

by

Claude McCrocklin

\section{Introduction}

This is a brief report on an archeological survey of James Bayou in East Texas that was organized to find the site of a large Historic Caddo Indian village that was reported to be in the area. Much is known about the village people. They were Kadohadacho Caddo from the Great Bend region of the Red River in Southwest Arkansas who had migrated to the area now known as James Bayou about 1800 (Bagur 1992, and this issue). The population of the village they established was reported to be near 500 people, and they stayed in the East Texas and Northwest Louisiana area into the early 1840s. However, none of the early contemporary writers who provide this information reported the exact location of the village, and thus the site's location was unknown when the survey was initiated.

As of this report, we have surveyed both sides of James Bayou from the Louisiana line to near Stratford Lake. This was our target area since the lower Louisiana part of the Bayou had been surveyed in 1986-1987 under my direction by Shreveport members of the Louisiana Archaeological Society. In all of this vast area the only sites found on both surveys old enough to be components of the Caddo village were in a four mile area along the 200-250 foot contour on the north and east sides of James Bayou. The ten sites found and tested seemed to have a date range of 1790 to. the $1840 \mathrm{~s}$, which is the same as the occupation range of the Caddo village. These sites could well be components of the village since no records that we can find report anyone else in that part of Spanish East Texas through the entire period.

The Sites

The sites old enough to be components of the Caddo village will not be described individually, but will be referred to as the "East" and "West" sites. With the exception of the large site 41 MR77 (Monterey Lake \#1) described in a separate report in preparation, all of the sites are small with sparse European trade goods.

Some of the site observations we have made are: 
1. Only $41 M R 77$ had table knives, forks, and spoons.

2 . There were no farming tools on any sites.

3. Horse-riding equipment, including bridle bits, buckles, spurs, and stirrups, were common.

4. The "West" sites have daub, thin middens and few domestic animal bones.

It is my impression that the "West" sites were earlier in time than those in the "East", and that the dwellings were simple wattle and daub structures instead of log cabins. This is based upon daub with twig, stick, and split board imprints, dirt floors, and very few square nails in the "West" sites. There were also no large, flat rocks on the "West" sites such as marked those in the "East".

No chimney falls were found in the "West" sites, but instead there were shallow cooking or fire pits in the dirt floors. The "East" sites, although similar in layout to the "West" site group, appear to have had log cabins with stone fireplaces. This is indicated by lots of flat stones in fire areas, an abundance of square nails of all sizes, as well as daub or chinking to fill the spaces between logs of a cabin. No window pane glass was found on any site, or any evidence suggesting the use of a board floor.

Other than similar European-manufactured ceramics, and other trade goods, the main types of artifacts that tie the sites together are chipped European ceramics, chipped bottle glass, and polished pebbles. Of these, the polished pebbles are the most curious, because we had found chipped European materials on other Historic Indian sites and were not surprised to find them on the James Bayou sites. No native pottery sherds were found on any of the sites, however. Some glass beads were found during troweling, but we did not specifically screen for them.

For those who say, "no pot sherds, no Indians", then somehow it must be explained what Anglo-Americans were doing in that time and place chipping European ceramics and polishing pebbles. It just might be that the results of the James Bayou survey may "change some thinking" of what to expect from late Historic Caddo sites, especially since none have been found previously to compare with the James Bayou artifacts.

\section{The Artifacts}

The large amount of artifacts from the survey have a different "look" than those we have found on contemporary Red River sites. Most of the European ceramics have a different design and pattern, and there are also some new bottle types; even the utensils look different. For instance, the large round-pointed curved table knives of British army type have not been found on any previous site I've worked on. Also, the bridle bits, the spur, and the stirrup found on $41 \mathrm{MR} 77$ appear to be of British design (the identification of these items came from the 1975 publication Collectors Illustrated Encyclopedia of the American Revolution by George C. 
Neumann and Frank Kovic). This difference in trade materials suggests another source of trade other than the U.S. trading posts along Red River. This in itself is intriguing, and would make an interesting study.

All of the artifacts from the survey are currently being studied by Dr. Timothy $K$. Perttula of the Texas Historical Commission in Austin, Texas. Please check with him for further information.

\section{Summary}

Whether or not we have found part of the Caddo village is open to debate. However, let us look at the results of the survey: (a) the sites are where they were supposed to be based upon the available research material, (b) they are of the right time period, (c) they have similar artifact types, and (d) no other sites early enough to be components of the village were found anywhere else in the James Bayou area.

It was not our intention to try and find all of the sites expected to be in the reported 500 person village. We did want to find enough of them to verify its location; we think that the 10 sites found did this. They, along with other probable sites found but not confirmed by testing (because they were either in people's yards or mostly destroyed by development), show a large dispersed line village emerging on the north side of James Bayou.

The James Bayou area is mostly dense woods and cut-over hill country grown up into thickets. This makes it difficult to survey, and we feel that we missed far more sites than we found. Those missed sites, along with the rest of the Caddo village, will remain for archeologists of the future to find. At least as the result of our survey, they will know where to look.

\section{Acknowledgements}

First, I want to thank the landowners who made the survey possible by granting permission to survey their land. They are John Haygood, Johnny Fitzgerald, Robert Harrell, George Parker, Danny Stanfield, C.C. Jones, John Corley, Chubby Jones of the Shingle Mill Hunting Club, and others. Those who helped with the field work were Harold Brice, Danny Stanfield, Craig Kennedy, David Stanfield, Pam Stanfield, Ruth Rainey, and Jean Robbins.

The professional archeological advisors were Dr. Timothy K. Perttula of the Texas Historical Commission and Dr. Frank Schambach of the Arkansas Archeological Survey. Dr. H.F. Gregory of Northwestern University in Natchitoches, Louisiana identified some of the artifacts.

\section{Sources}

Bagur, Jacques

1991 The Location of the Caddo Indian Village. MS. 


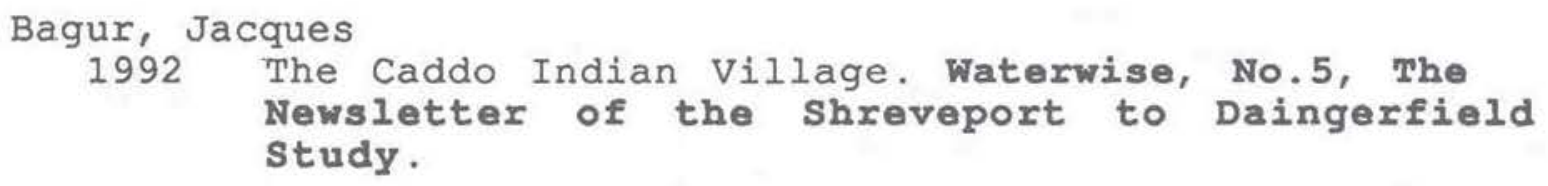

Darby, William

1816 Map of 1811 of Louisiana and part of Mississippi.

Flores, Dan L.

1984 Jefferson and Southwestern Exploration. University of Oklahoma Press, Norman.

Neumann, George C. and Frank Kovic

1975 Collectors Encyclopedia of the American Revolution. Rebel Publishing, Texarkana.

Sibley, John

1805 Historical Sketches of Several Indian Tribes in Louisiana. In American State Papers, Class II, Indian Affairs. Gale \& Seaton, Washington, D.C. 